UDC 614/5:644.36

DOI: $10.21668 /$ health.risk/2017.1.15.eng

\title{
DISORDERS IN MELANOPSIN EFFECT OF PUPIL CONSTRICTION AS A RISK FACTOR CAUSING EYE DISEASES
}

\author{
V.A. Kaptsov ${ }^{1}$, V.N.Dainego ${ }^{2}$ \\ ${ }^{1}$ All-Russian Research Institute of Railway Hygiene, 1 Pakgauznoe Shosse Str., Bldg. 1, Moscow, 125438, \\ Russian Faderation \\ ${ }^{2}$ Scientific-production company «ELTAN LTD», 2 Zavodskoy avenue, Fryazino, 141190, Russian Faderation
}

\begin{abstract}
Risks of eye damage and eyesight deterioration to a great extent depend on how efficient a biomechanical eye system is under energy-saving lighting conditions. The system's efficiency is determined by its adequacy in managing pupils and ciliary muscle.

We analyzed mathematical models describing changes in pupil's diameter which were determined by lighttechnical parameters of illumination environment (luminance level and brightness). We highlighted the importance of ganglionic cells and the role they play in managing pupil's diameter (miosis) when they are exposed to blue light within $480 \mathrm{~nm}$ spectrum. Basing on the assessment of a pupil's constriction under exposure to various light stimuli (blue, red, and green ones) we worked out a melanopsin effect concept of a pupil's retention at miosis and showed that it could be a diagnostic sign of some diseases (age-related direct retinopathy, pancreatic diabetes) under exposure to a blue light impulse with a certain wave length. Under exposure to blue light within $480 \mathrm{~nm}$ spectrum ganglionic cells form a managing signal for a sphincter muscle of a pupil and ciliary muscle which provides accommodation (as per Helmholtz) and regulates aqueous humor flow in ciliary channel.

All modern energy-saving light sources have a low energy level at wave length equal to $480 \mathrm{~nm}$ due to gap in their spectrum in comparison with sunlight spectrum with the same light temperature and luminance level. Inadequate management of pupil's diameter under artificial lighting conditions leads to melanopsin effect disorders and causes disharmony in managing aqueous humor outflow. All the above-stated factors under long-term visual load cause eye diseases risks in modern illumination environment.

We detected that contemporary mathematic models describing pupil's diameter fluctuations needed to be refined allowing for new knowledge on functional peculiarities of retina cells and energy-saving light sources spectrum.

Key words: biomechanical eye system, LED illumination, blue light, pupil constriction, ganglionic cells, melanopsin effect, myopia evolvement risk
\end{abstract}

Issues of contemporary illumination environment hygiene and growing risks for eyes diseases caused by light from artificial sources are intertwined. Light impacts on eyes depend on a pupil diameter size and light spectrum quality which programs managing functional structures of a visual analyzer. Inadequate program management of a human eyesight biomechanical system increases eyes diseases risks.

Nowadays people's illumination environment is determined by energy-saving light sources and information displaying devices.

Ophthalmologists and hygienists have assessed the results of mass implementing compact luminous lamps and LEDs in South Korea, Japan, and China; the assessment

(C) Kaptsov V.A., Dainego V.N., 2017

Valeriy A. Kaptsov - Corresponding Member of Russian Academy of Sciences, Doctor of Medical Sciences, prof., Head of the Occupational Health Department (e-mail: kapcovva39@ mail.ru; tel.: + 7 (499) 15-33-628). 07).

Vitaly N. Deinego - Project Manager for Lighting LLC (e-mail: aet@aetechnologies.ru; tel.: + 7 (495) 280-76- 
revealed that there was a similar trend existing in all these countries, namely constant and stable growth in myopia cases number. This issue significance is also highlighted by recent research conducted in South Korea (where people use compact luminous lamps and LEDs everywhere); the research results were almost surreal as practically $96.5 \%$ of all 19 -year-old (military age) men had myopia [41]. Historically human eyesight biomechanical system developed in sunlight environment and in unlimited visual space. "One can't get an insight into what the eye is without knowing the Sun. That's why the eye is solar, as a poet says", Sergey Ivanovich Vavilov told closing his wonderful book "Eye and Sun". Sunlight gets to retina through pupil and manages its size via relevant ganglionic cells and brain sections.

A man usually reacts negatively at brightblue light flashes. " Pupillary reflex is in blue zone of a spectrum. Blue light sends the strongest signal to muscles in iris in order to close a pupil" doctor David H. Sliney told, an expert of US army on physiological effects exerted by LEDs, laser and other sources of bright light, who worked at US Army Center on health improvement and prevention medicine. In his work "Ensuring safety in LED lighting" [29] he pointed out that ganglionic cells were very important for an eye protection as such cells could keep a pupil small. Rods and cones can cause only short-term pupil constriction and it then again dilates within approximately 10 seconds. David H. Sliney also told that pupil size was approximately equal to $2 \mathrm{~mm}$ outside and was backed by photo-sensitive ganglionic cells, and upper eyelid protected a retina part which was below it [43].

A key moment for an eye pupil in classic light technique is its response at a value which is proportionate to quantity of white light which gets to retina. A human pupil diameter can vary from 1.1 to $8.0 \mathrm{~mm}$.

Designers of optical devices with various functions were the first who paid certain attention to studying regularities in pupil diameter changes depending on luminance.
When such devices are used human sight is maximum limited in visual space. Without an insight into these regularities it is hardly possible to design a qualitative optical device. Researchers in their works were guided by an assumption that pupillary reflex could be caused by various reasons, but first of all, by changes in background brightness. As background brightness grows, pupil diameter goes down. In general, this dependence is expressed with a formula by V.V. Mashkov [11]:

$$
\mathrm{Dp}=5-3 \text { th }(0,4 \lg \mathrm{L}),
$$

where $\mathrm{Dp}$ is pupil diameter, $\mathrm{mm}$; $\mathrm{L}$ is background brightness, $\mathrm{cd} / \mathrm{m} 2$; th is hyperbolic tangent.

Dependence of pupil diameter on brightness calculated as per formula (1), is given on Figure 1 (curve 1).

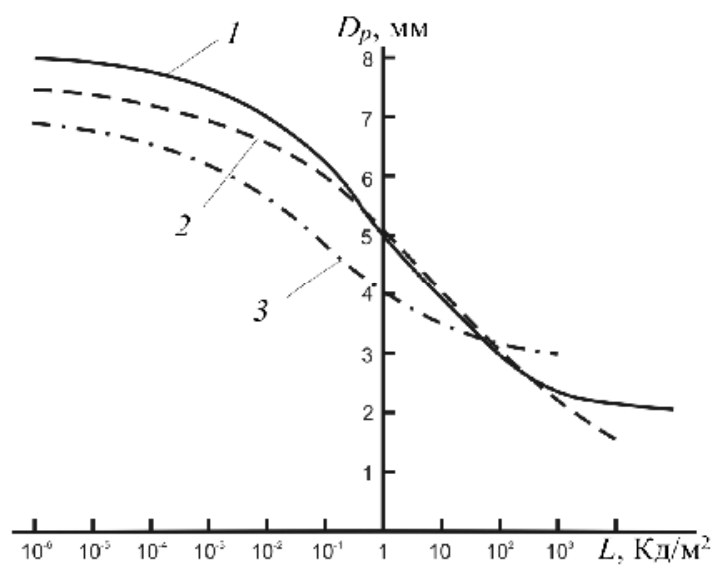

Figure 1. Dependence of eye pupil on background brightness. Broken line shows dependences obtained by R.Reeves (curve 2) and N.I. Pinegin (curve 3) [20]

N.I. Pinegin detected in his research that decrease in field angular size at constant brightness leads to pupil dilatation [13, 20]. T.N. Khatsevich examined dependence of pupil diameter in the process of watching images on electro-optical image convertor display (EOC) in night viewers [20]. Adaptation field (EOC display) peculiarities related to luminophor radiation, brightness fluctuation on a display, and scintillation occurrence, cause certain changes in pupillary response, namely, pupil size growth. And here 
dependence of pupil diameter on EOC display brightness is given by the next formula:

$$
\mathrm{Dp}=5,5-1,5 \operatorname{th}[0,5 \lg (0,06 \mathrm{~L})] \text {. }
$$

The formula is true at $10-4 \mathrm{~cd} / \mathrm{m}<\mathrm{L}<$ $102 \mathrm{~cd} / \mathrm{m}$., that is, at actual EOC display brightness which, as a rule, gleams with green light [22].

The given data analysis reveals that when retina is exposed to luminous light, all formulas for calculating eye pupil diameter are to be changed towards its growth [20].

Pupil diameter growth is caused not only by all the mentioned factors but also by eyes diseases occurrence (Figure 2).

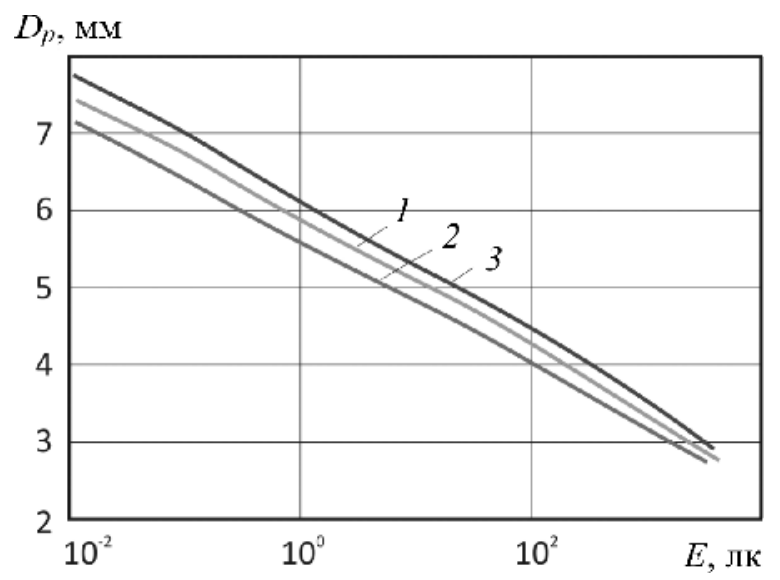

Figure 2. Dependence of eye pupil diameter on luminance on pupil: 1 is emmetropic eye; 2 is hypermetropic eye; 3 is myopic eye

When myopia occurs, eye pupil diameter is bigger than in case of normal eyesight. Diameter also depends on accommodation state and convergence state; when they are enhanced pupils contract, but when they get weaker, pupils dilate. Such changes can also occur when only accommodation or only convergence change [20].

As technologies developed, experts in the laser technique field responsible for photobiological safety joined specialists on telescopes, light technicians, and specialized optical devices designers. Mathematical models for changes in human pupil diameter were of great interest for domestic light technicians when they solved applied tasks. Photo-biological safety issues have got their attention only nowadays after mass implementation of LED lighting. Foreign research on laser safety underlies regulatory documents on light sources photo-biological safety; such research often applies mathematical models of pupil diameter dependence on luminance, brightness, and photon flow. John Marshall, professor of ophthalmology at University college in London, dealt with eyesight problems since 1965, when he received a grant from Royal Air Forces and examined devastating impacts exerted on retina by lasers. He claimed that at that time they needed a much better insight into a way light interacted with retina, and what mechanisms could potentially cause eye damage. He, together with German and American scientists, created a database which gave grounds for international codes of practices aimed at people protection from possible devastating impacts exerted by lasers. Researchers extended the obtained results on potentially devastating effects caused by incoherent light. Their achievements were included into codes of practices used by large international organizations, such as World Health Organization (WHO), UN ecological programs and International Red Cross [31].

First works on laser safety enabled visual alignment charts creation to compare various light sources and safety areas (as per doctor David H. Sliney). Pupil diameter is in the center of these alignment charts as it fully determines an object projection on eye retina. Also "blue danger" areas are given in the presented alignment chart. But as time passes, new discoveries are made and new standards for photo-biological safety are created. For example, in accordance with State Standard IEC/TR 60825-9-2013 on laser devices safety a new concept, maximum permissible exposure (MPE), was introduced; under normal conditions, the concept doesn't contradict the results of biological effects occurrence. MPE value depends on radiation wave length, exposure duration, tissue state and exposure area size. A source angular size determines an image size on retina for visible and near infrared radiation within a range from 380 to 1,400 nanometers; the image here greatly depends on eye pupil diameter. This state standard determines "blue danger" with maximum permissible exposure on an eye assessed within wave length range from 
380 to 1,400 nanometers and based on standard eye pupil size equal to $7 \mathrm{~mm}$ for duration shorter than $0.5 \mathrm{sec}$ and equal to $3 \mathrm{~mm}$ for duration longer than $0.5 \mathrm{sec}$. Depending on brightness of observed light field pupil diameter varies from values smaller than $2 \mathrm{~mm}$ and greater than $7 \mathrm{~mm}$ depending on individual peculiarities of a person, an object of observation, and age. Formula (3) can be applied to calculate pupil diameter $\mathrm{d} 3 \mathrm{p}(\mathrm{mm})$ depending on brightness value $\mathrm{L}(\mathrm{cd} / \mathrm{m})$ of an observed object.

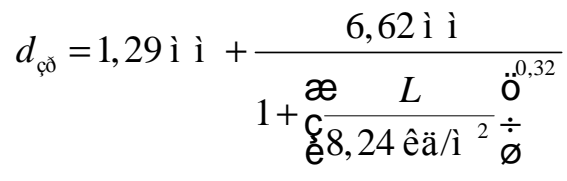

This formula is difficult for calculations. A clearer dependence of pupil diameter on brightness is given in State Standard IEC/TR 60825-9-2013 [4] (Figure 3).

MPE values correction within wave length range from 380 to 1,400 nanometers for duration $<0.5 \mathrm{sec}$ in case pupil diameter is of standard size is performed in proportional dependence on its square. When a light source is used under different lighting conditions (for example at daytime and at night), calculating safety at pupil diameter being equal to $7 \mathrm{~mm}$ is the most correct variant [4].

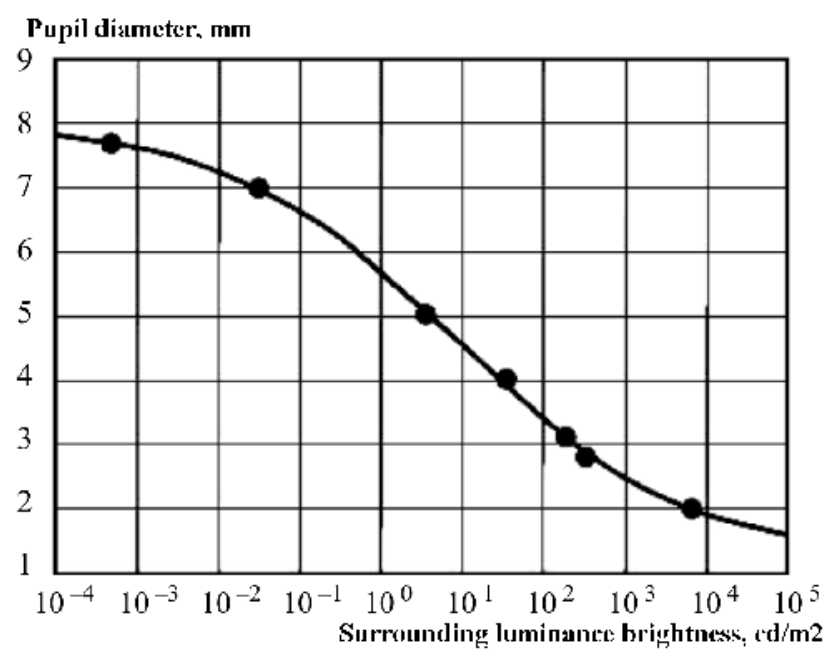

Figure 3. Pupil diameter dependence on an observed object brightness according to State Standard IEC/TR 60825-9-2013 [4]
A newly created State Standard P MEK 62471-2013 «Lamps and lamp systems. Lightbiological safety» [5] doesn't contain such comments. And we should point out that such regulatory document as State Standard IEC/TR 60825-9-2013 applied a mathematical model showing pupil diameter dependence on an observed field brightness in accordance with $P$. Reeves, JOSA 4, 35-43 (1920), and these are pupil diameter models which were created before 1920. To achieve their goals, A.B. Watson and J.I. Yellott, experts of NASA Research Center and Cognitive Sciences Department at California University, generalized existing mathematical models for pupil diameter dependence on brightness [46]. They created a new united formula which comprised brightness effects, adapting field size, and an observer's age. These researchers examined the following models: Holladay (1926); Crawford (1936); Moon and Spencer (1944); De Groot and Gebhard (1952); Winn, Whitaker, Elliott, and Phillips (1994); Stanley and Davies (1995); Barten (1999) and Blackie and Howland (1999). Summarized results are given on Figure 4.

Such a variety of mathematical models for pupil diameter dependence on brightness and other factors implies that these models are created under great uncertainty and lack of knowledge on how biomechanical system of eye pupil managing functions in modern lighting environment.

This uncertainty decreases as new discoveries in the sphere of eye cells functioning and their fitting together into a united biomechanical system for pupil diameter managing are made. This system operates according to functional systems laws by P.K. Anokhin. According to him, "...looking for a system as higher and more common functioning principle for many phenomena can give much better results than just only analytical techniques in studying particular processes". 


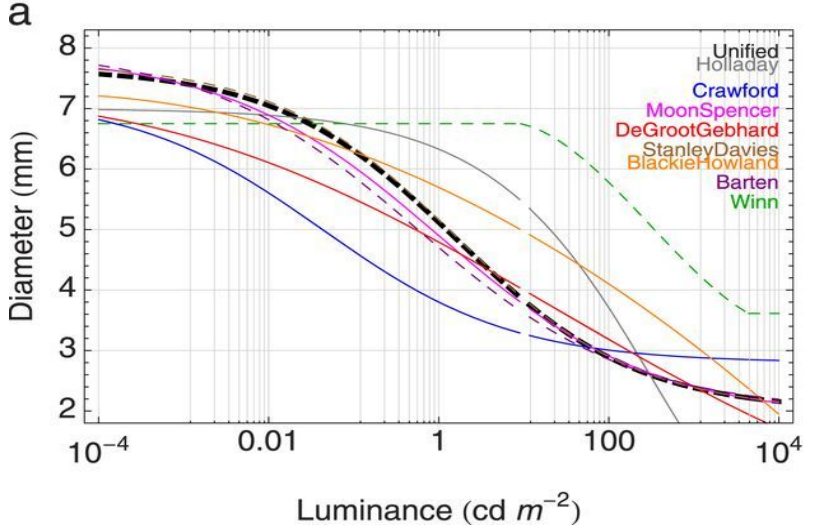

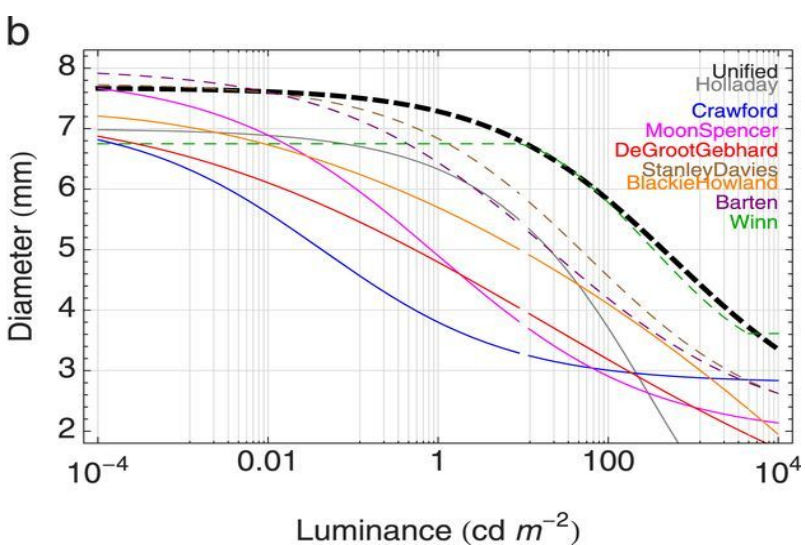

$\sigma$

Figure 4. Pupil diameter as per several formulas: $a$ is field diameter $60^{\circ}$, binocular sight; $\sigma$ is field diameter $10^{\circ}$, monocular sight. Broken lines show formulas, which depend on adaptation field size, an observer's age or binocularity. Volunteers' age for both figures is 30

In 1964 N. Viner, founder of cybernetics, stated that "Main issues of biology... are related systems and their organization in time and space". These concepts became a methodical ground for our analysis of visual analyzer functioning in modern lighting environment which differs from sunlight in terms of its spectrum form at a fixed luminance level.

Scientists for more than 150 years thought that a human eye contained only photoreceptor cells, rods and cones, which interacted and enabled accumulating visual experience by a person via brain visual cortex. It was thought that only those cells which transformed light spectrum into code messages of managing signals provided information for an eye biomechanical system to support sight quality in lighting environment.

Peculiar light-sensitive ganglionic cells of ipRGC type (intrinsically photosensitive retinal ganglion cells), or mRGC type (melanopsincontaining retinal ganglion cells) were discovered [3].

Such cells, as opposed to previously discovered ganglionic cells, contain lightsensitive pigment melanopsin which is different from other photosensitive eye pigments, rhodopsin of rods and iodopsin of cones which are unable to response directly to blue light in 480 nanometers range. These light-sensitive ganglionic cells are a new, third type of eye retina photoreceptors. As opposed to rods and cones known for 200 years, they are directly excited under exposure to light even when "classic" eye photoreceptors are blocked [34].

Due to research accomplished in various medical centers and universities in the USA and England it was determined that melanopsins have different subtypes with individual light sensitivity. Photo-ganglionic cells of $\mathrm{M}$ type are being examined most intensely. Melanopsin is a light-sensitive substance of these cells; it responses within wide range of colors, from 480 to 460 nanometers. M1 subtype melanopsin has two peaks of maximum sensitivity to blue light, namely:

- M1 Brn3b- at 460 nanometers;

- M1 Brn3b+ at 480 nanometers.

As new information is accumulated, a general form of curves showing M1type melanopsin spectral sensitivity is adjusted. It is detected that efficiency of managing eye pupil diameter at closing with M1 Brn3b+ melanopsin is determined by a curve for a person able to see and for a blind one [34]. A research on changes in pupil diameter depending on melanopsin excitement degree was also accomplished [26].

Only high irradiance by light of 480 nanometers (more > $11 \log$ photons cm-2 c-1) caused significantly more stable response in the form of pupil constriction over time in people able to see [34]. 
Nowadays large-scale research is being conducted in world centers; it focuses on assessing influence exerted by human and animal visual analyzer on light stimuli (blue, green, and red light) [23, 24]. A standard response is taken to analyze this reaction (Figure 5).

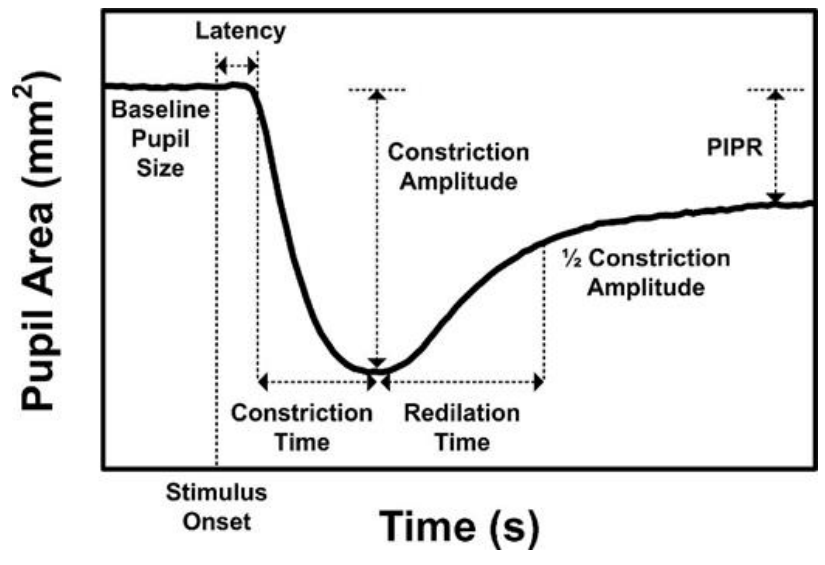

Figure 5. Pupil response dependence on contracting light impulse [23]

Standard response is characterized with baseline pupil size (without a light stimulus), maximum pupil constriction amplitude (under exposure to a light stimulus), and postillumination pupil response), PIPR. It is PIPR parameter that provides information on efficiency of managing pupil constrictions.

To perform mass examination of ganglionic cells contribution into managing pupil size at different light stimuli, mice's pupils are usually taken as research objects. Research conducted on mice revealed that a pupil contracted significantly greater under 480 nanometers blue light than under red light [24].

Analogous research was conducted on two volunteers groups. Volunteers in one group had good eyesight, but volunteers in the second group were blind [34].

Pupil diameter was proved to be equal to $4.19 \mathrm{~mm}$ under luminous lighting of $4,000 \mathrm{~K}$, luminance on cornea being 135 lumen 1.14.1014 (photons $/ \mathrm{cm}^{2} / \mathrm{s}$ ) and calculated irradiance of eye retina by light stimuli being $0,54 \mathrm{mw} / \mathrm{cm}^{2}$. It is the evidence that lighting by a luminous lamp at a dip in 480 nanometers area of a spectrum exerts complex influence. Soomin Lee et al. in their work describe light stimuli impacts exerted by two color lights (blue, 470 nanometers, and green, 532 nanometers) and by blue light separately on volunteers' eyes [28]. The resulting PIPR responses are given in Figure 6.

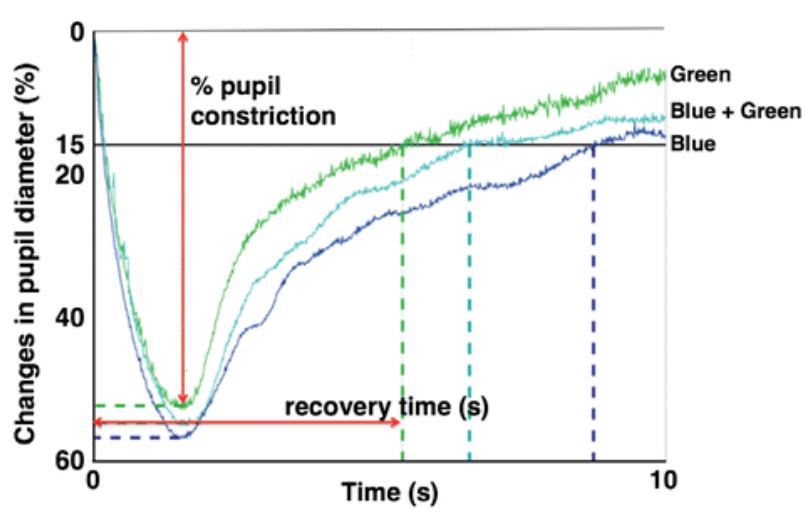

Figure 6. Changes in Japanese volunteers' pupil diameter at separate and simultaneous exposure to impulses of blue (470 nanometers) and green (532 nanometers) light (light source was a matrix with separate LEDs with a dip in 480 nanometers area)

The given dependence clearly shows why pupil diameter grows in EOC photooptic devices, and formula (2) allow for this growth.

Nowadays research on assessing PIPR value employs sources of blue and red light with various wave length, allowing for drug stimulation of an eye. Thus, to assess PIPR value, D.H. McDougal and P.D.R. Gamlin applied sources of red light with 613 nanometers length and blue light with 493 nanometers length in their work (Figure 7).

The third type are circular muscle fibers (Muller's muscle). They consist of separate fiber bundles which don't form compact muscle mass and have circular direction. They are located in anterointernal section of ciliary body, at interior edge. These fibers are considered to be a part of radial muscle. When radial and circular sections of ciliary muscle contract, a lumen of a rim formed by ciliary muscle decreases, and thus a place of Zinn ligament fixation gets closer to lens equator, resulting in lens curvature growth. 


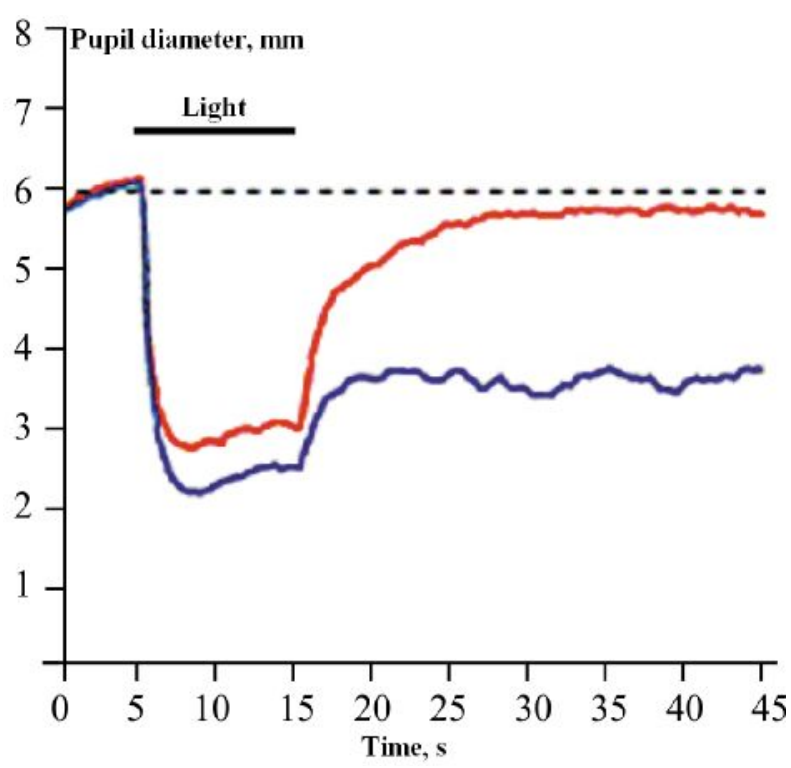

Figure 7. Pupil constriction induced by a light stimulus lasting for $10 \mathrm{sec}$ with 493 nanometers wave length at $14.0 \log$ quanta cm-2 s-1 irradiance (blue curve) and 613 nanometers wave length at $14.0 \log$ quanta cm-2 s-1 irradiance (red curve)

The fourth type are iridal muscle fibers (Calasans' muscle) located at the junction of iris root and ciliary muscle. They are a thin bundle of muscle fibers going to iris root. Obviously, they regulate a gap between iris and lens providing minimal dynamic resistance for aqueous humor outflow from posterior chamber into anterior one.

Joint functioning of all above-mentioned fibers provides for accommodation. When ciliary muscle is strained, ligaments relax thus reducing lens capsule strain. Here lens form becomes round, and lens itself moves along optical axis towards iris. General scheme of such movements is given in works byI.N. Koshitsa, an expert in biomechanics. But movement models are well studied in adults, not in children. Ciliary body is rich with nerve endings, however, it is not developed enough in newborns, therefore a lot of diseases evolve without any pain. Only by 7-10 years of age all functions of ciliary body are completely developed $[2,12,21]$. Given this fact, it is very important that artificial lighting environment has a spectrum which is relevant to sunlight.
Examining an object at close distance in any age is accompanied with accommodation, convergence, and pupil constriction. With the help of these three physiological mechanisms better perception and better vision of an examined object becomes possible. Essentially all three phenomena are part of just one act, namely setting eyes at close distance. Previously there was a lot of argument whether pupil constriction during examining an object at close distance was related to accommodation or convergence. But it turned out to be related to both processes. Pupils constriction when eyes are set at close distance occurs only when an object is $40 \mathrm{~cm}$ away from eyes or closer. Pupil constriction is most clearly visible when an object is $15-20 \mathrm{~cm}$ away from eyes. Figure 8 presents a dependence for pupil diameter changes on accommodation level.

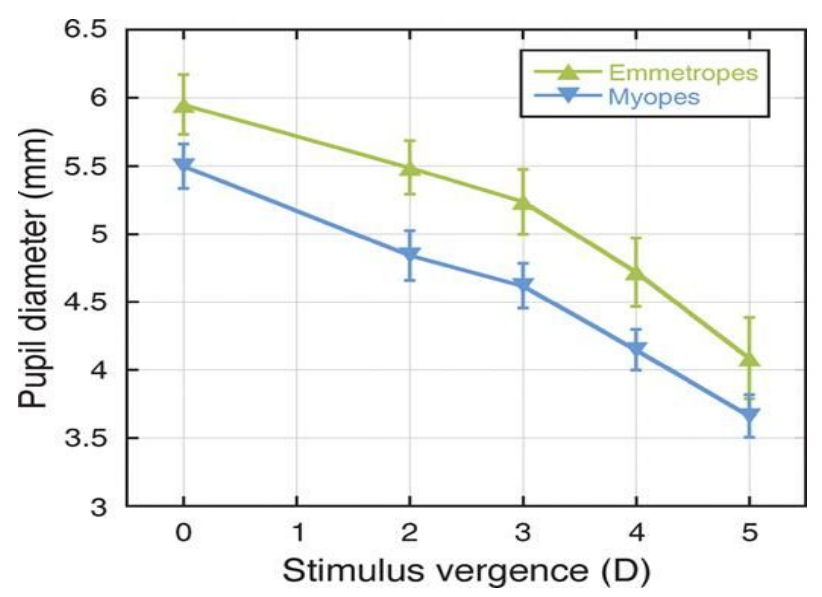

Figure 8. Dependence for pupil diameter changes on accommodation level [44]

The most recognized accommodation theory is Hermholz's theory; he proved that when accommodation strain is at maximum, anteroposterior lens size increases from 3.6 to $4.0 \mathrm{~mm}$, curvature radius of lens anterior surface drops from $10 \mathrm{~mm}$ to $6 \mathrm{~mm}$, and posterior surface, from 6.0 to $5.6 \mathrm{~mm}$ [19]. The higher is accommodation level, the smaller is anterior radius of lens which has certain physical and age limits [37]. 
Decrease in lens curvature and its moving towards iris leads to additional strain in Calasans' muscle for providing an adequate gap between iris and lens, that is equal inflow and outflow of aqueous humor. In 2010 Janice Tarrant et al. examined correlation between lens curvature, image clearness, wavefront aberrations, and accommodation processes [44]. They applied wavefront analyzer in their works to measure eye aberration in 13 volunteers with good eyesight (emmetropes) and 17 volunteers with myopia needed for examining 4 objects at various distances. When an examined object was moved closer, pupil constriction at first was rather slight, but then they contracted quite rapidly. An additional pupil constriction occurs when accommodation and convergence enhance synergizingly. Pupil constriction range at setting eyes at close distance varies a lot [16, 37, 39]. It implies that ciliary muscle is strained greater in case of myopia than in case of emmetropia. In this situation lens is more convex, and initial violation of balance between aqueous humor inflow and outflow occurs.

Pupil constriction and retention mechanism at accommodation and convergence is interesting for researchers when they solve applied tasks [25, 27]. Researchers in their experiments applied LCD-displays, OLEDmicrodisplays, and a white sheet of paper with letters lit by an incandescent lamp, to create visual images. Influence exerted by $480 \mathrm{~nm}$ blue light on managing pupil diameter when luminance came from a light source which differed from sunlight, was of particular interest for scientists. Some authors used letter on LCDdisplay and OLED-miscrodisplay (eMagin, CШA) as a visual stimulus [25]. Luminance level was about $15 \mathrm{~cd} / \mathrm{m}^{2}$. Two situations were examined: far (LCD-display), $2.75 \mathrm{~m}$ away; close (OLED-miscrodisplay), $30 \mathrm{~cm}$ away. Examinations involved volunteers' participation; they were young people aged $27.8 \pm 2.4$.

Other researchers use LCD-display for watching movies as a visual stimulus, and their volunteers were children (a very relevant focus group nowadays) aged from 6 to 16 [27]: 76 were regularly developed children and 41 children had Down's syndrome (DS). Research allowed to obtain dependence of changes in pupil diameter on accommodation level (Figure 9).

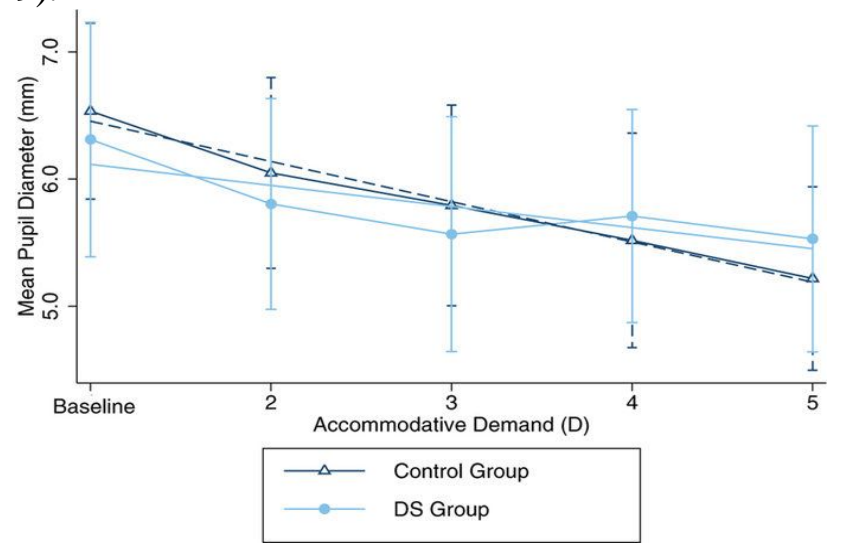

Figure 9. Dependence of changes in pupil diameter on accommodation level

S.Plainis in his work used the letter "E" printed on white paper lit by an incandescent lamp as an observation object [40]. Background brightness was equal to $5 \mathrm{~cd} / \mathrm{m} 2$. Nevertheless, eye retina illumination was not constant for each object and level placement due to discrepancies in pupil sizes. All measurements were performed on natural pupils without introducing any drugs (mydriatic or cycloplegic). Seven volunteers aged from 23 to 33 (average age was 28) took part in this research. Four volunteers had normal eyesight (emmetropes), and three had bad eyesight (myopes) (ranged from -2.00 to $2.50 \mathrm{D})$, adjusted with glasses [40]. The greater adaptation response was, the bigger was miosis degree, and the correlation was linear. Each accommodation diopter induces $0.18 \mathrm{~mm}$ pupil constriction. Linear character of the dependence correlates well with the dependence given in Figure 9.

With mutual bracing of lens, iris, ciliary muscle and high sensitivity of pupil diameter managing system in mind, we can draw up a mathematical model (formula 4) for actual pupil diameter value at its closing under lighting environment when certain visual functions are performed.

$\mathrm{D}_{\mathrm{ac}}=\mathrm{D}_{\mathrm{in}}(\mathrm{E}, \lambda)-\Delta \mathrm{D}(\mathrm{A})-\Delta \mathrm{D}(\mathrm{K}),(4)$ 
where $D_{\text {in }}(E, \lambda)$ is initial pupil diameter at environment illumination and light spectrum;

$\Delta \mathrm{D}(\mathrm{A})$ is a change in pupil diameter at accommodation induced by ciliary muscle strain degree (Bruecke's muscle, Ivanov's muscle, Muller's muscle, and Calasans' muscle);

$\Delta \mathrm{D}(\mathrm{K})$ is changes in pupil diameter at convergence.

From methodical point of view it is very important to understand what figure a current pupil diameter value goes to when visual functioning take place.

Visual perception quality depends on retina resolution ability, light diffraction in pupil area, and peculiarities of eyes optical media. One of peculiarities a human eye has is occurrence of focal area depth, and there can't be any changes in image quality within its boundaries. Hence, there is an optimal sufficient pupil diameter value which provides such focal adjustment.

Visual perception is regulated not only by physiological optics but also by cortical structures of central nervous system. Improving eye optics via decrease in aberration, one can increase visual resolution from an ordinary level to higher one.

Aberration can be chromatic, diffractive, and spherical.

Chromatic aberration is an image distortion related to a situation when visible light rays with different wave length fall on lens in a parallel bundle, refract, and then don't focus in one point. Short-wave rays (bluegreen) focus further from retina than longwave (red) ones. This phenomenon is called longitudinal chromatic aberration. As a result an image is blurred and its edges are painted. If a blue rays focus is superposed with retina, a point image is surrounded with red aureole, and vice versa. Perceived objects shapes can be painted red in case of hypermetropia, and blue, in case of myopia. Under lighting with white light a man doesn't discern color edges around observed objects. It is explained by color aureoles overlapping each other and small angular sized of color edges. Chromatic aberrations don't exert any significant influence on central vision.
Diffractive aberration is related to disorder in linearity, light wave deviation during its spread by sharp edges of opaque or translucent structures which form holes. A pupil is an example of such structure in an eye. Due to light diffraction at a pupil edge where a clear transition from shadow to light should take place according to geometric optics laws, a number of light and dark diffraction rims occur and they are projected on retina. As a pupil diameter decreases, a diameter of light scattering diffraction rim increases. But spherical aberration also decreases.

Spherical aberration is a state, when there are discrepancies in a light ray refraction between a center of spherical optical surface and its periphery. Lens and cornea curvature underlies spherical aberration. Influence which spherical aberration has on image quality depends on pupil size. When pupil size is small (from $2 \mathrm{~mm}$ to $4 \mathrm{~mm}$ ), spherical aberration is minimal, but it grows drastically as a pupil dilates. To maintain image quality at maximum level simultaneously providing minimal levels of diffractive and spherical aberration, we need to provide optimal sufficient pupil diameter value $\left(\mathrm{D}_{\mathrm{os}}\right)$ not only for securing minimal aberration level but also for securing accommodation process (5) [1].

$$
\mathrm{D}_{\mathrm{os}}=\mathrm{D}_{\text {in }}(\mathrm{E}, \lambda)-\Delta \mathrm{D}(\mathrm{A})-\Delta \mathrm{D}(\mathrm{K})=\text { const. }
$$

Din $(E, \lambda)$ forms environment illumination and light spectrum

All modern energy-saving light sources have low energy level at wave length equal to $480 \mathrm{~nm}$ due to a dip in this area as opposed to sunlight spectrum with the same color temperature and luminance. Inadequate functioning of pupil diameter management channel under artificial lighting leads to disorders in melanopsin effect of pupil retention at its constriction. And this, in its turn, results in additional efforts of ciliary muscle required for maintaining qualitative vision. All this together causes eye diseases risks under long-term visual load in modern lighting environment. 
When there is residual strain in ciliary muscle or it suffers from grave overstrain, aqueous humor inflow and outflow balance is violated. I.N. Koshits et al. described contribution such violation makes into myopia evolvement in great details [17, 18]. Due to their research results and description of mechanisms regulating uveal scleral outflow path it became possible to get better understanding of a role which radial and circular parts of ciliary muscle (Ivanov's muscle and Muller's muscle) play in active regulation of uveal scleral outflow path in an eye.

Average speed at which aqueous humor is produced in a human eye equals to about 2 $\mathrm{mm} 3 / \mathrm{min}$ as per physiological standard, changes range as per physiological standard amounts to $1.5-4.5 \mathrm{~mm} 3 / \mathrm{min}$. A period of aqueous humor renewal in an eye amounts to $90 \mathrm{~min}$, that is, approximately $3 \mathrm{ml}(3 \mathrm{~cm} 3)$ of aqueous humor flows through an eye anterior section daily with average eye volume being less than $7.5 \mathrm{~mm} 3$. Slight variations in intraocular fluid production or outflow will have significant influence on intraocular pressure [14].

To provide efficiency and precise functioning of muscles which manage flows it is necessary: 1) that signals coming to Edinger-Westphal nucleus entrance were formed under sunlight impacts on retina cells; 2) that sunlight spectrum adapted visual analyzer structure to adequate algorithms of functional elements work to provide vision quality together with minimizing diseases risks. Sunlight spectrum, with hygienic limitations taken into accounts, manages Brueecke's muscle, Muller's muscle, and Ivanov's muscle state quite adequately; it also does so in case of aqueous humor outflow valves which are described in works by I.N. Koshits et al. [17]. We also considered Calasans' muscle state as this muscle manages a size of a gap between iris and lens at accommodation. "Iris - lens" valve role and functioning wasn't given enough attention in above- mentioned models for managing aqueous humor flow [17]. Although a role this gap plays in glaucoma evolvement is vividly discussed in works which describe models for this disease evolvement, Calasans' muscle state (its degeneration) is neglected in them. Notably, experts from Biomedical Engineering Department and Chemical and Materials Technology Faculty at Minnesota University performed mathematical modeling of accommodation microfluctuations processes and iris shape [30]. Research is going on now but their models don't allow for Calasans' muscle functioning.

Drug models for various tonic states of ciliary muscle were used to detect that accommodation apparatus functioning is directly related to an eye hydrodynamics; flow direction and volumes of liquid depend on accommodation fluctuations amplitude. Light spectrum which is not adequate to sunlight spectrum leads to disharmonizing in the way functional elements of visual analyzer operate. It becomes visible through:

- a dilated pupil when $480 \mathrm{~nm}$ light is absent in a spectrum which is characteristic for energy-saving lighting and displays lighting;

- disorder in rhodopsin synthesis out of vitamin A, a dip in 380 and $480 \mathrm{~nm}$ spectrum;

- dried eyes syndrome when working at displays which proves there is a disorder in aqueous humor management;

- an ascending trend in intraocular pressure after long-term (5 hours) staying under LED-lighting [8]. Thus, intraocular pressure measured via non-contact tonometry (Tn) amounted to $17.35 \pm 1.1 \mathrm{~mm}$ $\mathrm{Hg}$ before the research and to $17.67 \pm 1.1$ $\mathrm{mm} \mathrm{Hg}$ after it was over (5 days) at luminance being 400 meter-candela and correlated light temperature being 4,0004,500 K [30].

As for apparent intraocular pressure, low standard zone for it $(9-12 \mathrm{~mm} \mathrm{Hg})$, average standard zone $(13-16 \mathrm{~mm} \mathrm{Hg}$ ) and 
high standards zone (17-22 $\mathrm{mm} \mathrm{Hg}$ ) depend both on anatomic peculiarities of venous sinus position and on peculiarities of ciliary muscle fixing to scleral spur. It all shows that under artificial lighting aqueous humor management is disharmonized due to additional compensation for inefficient pupil constriction management which ciliary body muscles have to perform when an object is observed at a close distance. Accumulated strain in muscles managing aqueous humor flows leads to greater risks for increased uncertainty in managing state of trabecular and uveal scleral ways valves. Here disorder in "inflow" and "outflow" equality results in forming its excessive quantities thus creating conditions for accelerated stretching of en eye optical axis.

Average length of a human eye from cornea to retina center amounts to $23.5 \mathrm{~mm}$. Each $1 \mathrm{~mm}$ increase in its length adds 3.0 diopter of myopia.

Persistent disorders in aqueous humor outflow can cause glaucoma, choroidal neovascularization, and macular degeneration [8, 28, 33]. As for cataract, there is various research on its relation to high degree myopia [36].

When disorders occur in melanopsin effect of pupil retention at its constriction, systematic destructive changes in eye functional elements take place. Persistent inadequate pupil diameter management becomes a systematic stimulus under contemporary lighting conditions and in information displaying devices; it creates an additional load on accommodation and convergence mechanism.

\section{Conclusions:}

1. Modern mathematic models for pupil diameter fluctuations require adjustment allowing for new knowledge on functional peculiarities of retina cells and spectra of energy-saving light sources.

2. We formulated conditions for melanopsin effect of pupil retention at its constriction in lighting environment; these conditions envisage an obligatory dose of 480 $\mathrm{nm}$ blue light in a spectrum of any artificial light source.

3. Inadequate pupil diameter management under artificial lighting conditions leads to disorders in melanopsin effect of pupil retention at its constriction and additional work of ciliary muscle needed for maintaining qualitative eyesight and keeping balance in aqueous humor inflow and outflow. All this together with long-term visual load leads to greater risks for eye diseases evolvement in modern lighting environment.

\section{References}

1. Avetisov S.E., Sheludchenko V.M. Nuzhno li nam super-zrenie? Aberratsii glaza [Do we need super sight? Eye aberration]. Klinicheskaya fiziologiya glaza, 2006, pp. 488-501. Available at: http://miroft.org.ua/origunalarts/315.html (13.10.2016).

2. Bakutkin V.V., Kirichuk V.F., Kuznetsova E.V. Vliyanie dinamicheskoi elektroneirostimulyatsii na akkomodatsionnye sposobnosti glaza cheloveka [Influence exerted by electrical neurostimulation on accommodation capacity of a human eye]. Problemy opticheskoi fiziki i biofotoniki: materialy XIII Mezhdunar. Molodezhnoi nauchnoi shkoly po optike, lazernoi fizike i biofotonike [Issues of optical physics and biophotonics: materials of XIII International Youth scientific school on optics, laser physics and biophotonics]. Saratov, Novyi veter Publ., 2009, 219 p. (in Russian).

3. Berman S.M., Klier R.D. Nedavno otkrytyi fotoretseptor cheloveka i predydushchie issledovaniya v oblasti zreniya. Svetotekhnika, 2008, no. 3, pp. 49-53.

4. GOST IEC/TR 60825-9-2013. Bezopasnost' lazernoi apparatury. Chast' 9. Kompilyatsiya maksimal'no dopustimoi ekspozitsii nekogerentnogo opticheskogo izlucheniya [State Standard IEC/TR 60825-9-2013. Laser equipment safety. Part 9. Compilation of maximum allowable exposure to incoherent 
optical radiation]. Moscow, Standartinform Publ., 2014, 36 p. Available at: http://gostpdf.ru/cont/files/608259-2013/gost-60825-9-2013.13333.pdf (02.10.2016).

5. GOST R MEK 62471-2013. Lampy i lampovye sistemy. Svetobiologicheskaya bezopasnost' [Lamps and lamp systems. Light-biological safety]. Available at: http://docs.cntd.ru/document/1200104817 (10.10.2016).

6. Deinego V.N., Kaptsov V.A. Svet energosberegayushchikh i svetodiodnykh lamp i zdorov'e cheloveka [Energy saving and led lamp lighting and human health]. Gigiena $i$ sanitariya, 2013, no. 6, pp. 81-84 (in Russian).

7. Dorosheva E.A. Evolyutsionnyi podkhod k voprosam formirovaniya blizorukosti: perestroika zritel'nogo analizatora kak adaptatsiya $\mathrm{k}$ sotsiokul'turnym usloviyam [Evolutionary approach to the formation of myopia: the restructuring of the visual analyzer as an adaptation to the social and cultural conditions]. Eksperimental'naya psikhologiya, 2014, vol. 7, no. 3, pp. 83-96 (in Russian).

8. Osiko M.V., Gizinger O.A., Telesheva L.F., Dolgushin I.I., Ogneva O.I., Fedosov A.A., Kudryashov A.V., Vakhitov M.G., Kalinina A.S. Issledovanie effektivnosti i bezopasnosti dlya zdorov'ya svetodiodnykh istochnikov sveta [Study of led light source effectiveness and health safety]. Sovremennye problemy nauki i obrazovaniya, 2013, no. 6, pp. 566 (in Russian).

9. Koshits I.N., Svetlova O.V., Makarov F.N., Shilkin G.A. Klassifikatsiya ispolnitel'nykh mekhanizmov «predmetnoi» akkomodatsii u cheloveka [Classification of actuating mechanisms of objective accommodation in human being]. Rossiiskaya detskaya oftal'mologiya, 2012, no. 4, pp. 28-36 (in Russian).

10. Klinicheskaya anatomiya organa zreniya: Chasti tsiliarnogo tela [Clinical anatomy of sight organ: Ciliary body parts]. StudFiles: failovyi arkhiv studentov. Available at: http://www.studfiles.ru/preview/2243441/page:7/ (15.10.2016).

11. Meshkov V.V. Osnova svetotekhniki [Basics of lighting technology]. Moscow, Leningrad, Gosenergoizdat, 1961, 416 p. (in Russian).

12. Nikolaenko G.A. Tsiliarnoe telo glaza cheloveka v ontogeneze: dis... kand. med. nauk. [Ciliary body of a human eye in ontogenesis: thesis... candidate of medical sciences]. Vladivostok, Vladivostokskii Gosudarstvennyi Meditsinskii Universitet Publ., 2005, 140 p. (in Russian).

13. Penegin N.I. Vliyanie yarkosti i razmera polya zreniya na diametr zrachka [Influence exerted by visual field brightness and size on pupil diameter]. Trududy I konf. po fiziol. Optike [Materials of the I Conference on physiological optics]. Moscow, Leningrad, 1936, 396 p. (in Russian).

14. Pershin B.S. Gidrodinamicheskii balans glaznogo yabloka pri intravitreal'nom vvedenii dopolnitel'nogo ob"ema zhidkosti (eksperimental'no-klinicheskoe issledovanie): dis. ... kand. med. nauk. [Eye ball hydrodynamic balance at intravitreal injection of additional fluid volume (experimental clinical research): thesis... candidate of medical sciences]. Moscow, 2012, 124 p. (in Russian).

15. Deinego V.N., Kaptsov V.A., Balashevich L.I., Svetlova O.V., Makarov F.N., Guseva M.G., Koshits I.N. Profilaktika glaznykh zabolevanii u detei i podrostkov v uchebnykh pomeshcheniyakh so svetodiodnymi istochnikami sveta pervogo pokoleniya [Prevention of ocular diseases in children and teenager in classrooms with led light sources of the first generation]. Rossiiskaya detskaya oftal'mologiya, 2016, no. 2, pp. 57-72 (in Russian).

16. Reaktsiya zrachkov pri ustanovke glaz na blizkoe rasstoyanie [Pupils' reaction at setting eyes for a close distance]. Sovremennaya oftal'mologiya: informatsionnyi portal. Available at: http://zrenue.com/nejrooftalmologija/51-normalnye-reakcii-suzhenija-zrachkov/387-reakcija-zrachka-pri-ustanovke-glaz-na-blizkoerasstojanie.html (15.10.2016).

17. Svetlova O.V., Koshits I.N. Vzaimodeistvie osnovnykh putei ottoka vnutriglaznoi zhidkosti s mekhanizmom akkomodatsii: Uchebnoe posobie [Interaction between basic ways of intraocular fluid outflow and accommodation mechanism: tutorial]. Izdat. Dom Spb.MAPO, 2002, 50 p. (in Russian).

18. Svetlova O.V., Koshits I.N., Drozdova G.A. Vzaimodeistvie mekhanizmov ottoka vodyanistoi vlagi i akkomodatsii pri miopii i glaukome. Patologicheskaya fiziologiya glaza: monografiya [Interaction between mechanisms of aqueous humor outflow and accommodation at myopia and glaucoma. Eye physiopathology: monograph]. 2-e izd, ispr. i dop. St. Petersburg, SZGMU im. I.I. Mechnikova Publ., 2016, 160 p. (in Russian).

19. Fedorov S.N., Yartseva N.S., Ismankulov A.O. Refraktsiya i akkomodatsiya. Glaznye bolezni [Refraction and accommodation. Eye diseases]. 2-e izd., pererab. i dop. Moscow, 2005, 440 p. (in Russian). 
20. Khatsevich T.N. Meditsinskie opticheskie pribory: Fiziologicheskaya optika: uchebnoe posobie [Medical optical instruments: Physiological optics: tutorial]. Novosibirsk: SGGA Publ., 1998, part. 1, 98 p. (in Russian).

21. Tsiliarnoe telo [Ciliary body]. Vse novosti oftal'mologii: natsional'nyi oftal'mologicheskii proekt. Available at: http://www.eyenews.ru/12/13/112 (15.10.2016).

22. Elektronno-opticheskii preobrazovatel' (EOP) [Electrooptical converter (EOC)]. Available at: http://go-radio.ru/electronno-opticheskiy-preobrazovatel.html (10.10.2016).

23. Adhikari P., Zele A.J., Feigl B. Post-Illumination Pupil Response. Investigative Ophthalmology \& Visual Science, 2015, vol.56, pp. 3838-3849. DOI:10.1167/iovs.14-16233.

24. Mohan K., Harper M.M., Kecova H., Ye E.A., Lazic T., Sakaguchi D.S., Kardon R.H., Grozdanic S.D. Characterization of structure and function of the mouse retina using pattern electroretinography, pupil light reflex, and optical coherence tomography. Vet Ophthalmol, 2012, vol. 15, no. 2, pp. 94-104. DOI: 10.1111/j.1463-5224.2012.01034.

25. Chirre E., Prieto P.M., Artal P. Dynamics of the near response under natural viewing conditions with an open-view sensor. Biomed. Opt. Express, 2015, vol. 6, no.10, pp. 4200-4211. DOI: 10.1364/BOE.6.004200

26. Tsujimura Sei-ichi, Ukai K., Ohama D., Nuruki A., Yunokuchi K. Contribution of human melanopsin retinal ganglion cells to steady-state pupil responses. Proc. R. Soc. B, 2010, vol. 277, pp. 2485-2492. DOI:10.1098/rspb.2010.0330.

27. Doyle L., Saunders K.J., Little J.-A. Trying to see, failing to focus: near visual impairment in Down syndrome. Scientific Reports, 2016. DOI: 10.1038/srep20444. Available at: http://www.nature.com/articles/ srep20444 (15.10.2016).

28. Lee S., Ishibashi S., Shimomura Y., Katsuura T. Effect of simultaneous exposure to extremely short pulses of blue and green light on human pupillary constriction. Journal of Physiological Anthropology, 2016, vol.35, pp. 20. DOI: 10.1186/s40101-016-0109-3

29. Ensuring safety in LED lighting. Electronics Weekly.com, 2012. Available at: http://www.electronicsweekly.com/news/products/led/ensuring-safety-in-led-lighting-2012-11 (02.10.2016).

30. Huang E.C., Barocas V.H. Accommodative microfluctuations and iris contour. Journal of Vision, 2006, vol.6, no. 5, pp. 653-660.

31. Marshall J. Understanding risks of phototoxicity on the eye. Points de Vue, International Review of Ophthalmic Optics, 2014, no. 71. Available at: http://www.pointsdevue.com/article/understanding-risks-phototoxicity-eye (10.10.2016).

32. Maynard M.L., Zele A.J., Feigl B. Melanopsin-Mediated Post-Illumination Pupil Response in Early Age-Related Macular Degeneration. Investigative Ophthalmology \& Visual Science October, 2015, vol.56, pp. 6906-6913. DOI:10.1167/iovs.15-17357.

33. McDougal D.H., Gamlin P.D.R. Pupillary Control Pathways. The Senses: A Comprehensive Reference, 2008, vol. 1, pp. 521-536.

34. Gooley J.J., Mien I.H., Hilaire M.A.St., Yeo S.-C., Chua Chern-Pin E., van Reen E., Hanley C.J., Hull J.T., Czeisler C.A., Lockley S.W. Melanopsin and Rod-Cone Photoreceptors Play Different Roles in Mediating Pupillary Light Responses during Exposure to Continuous Light in Humans Меланопсин и Род-Cone Humans. Journal of Neuroscience, 2012, vol. 32, no. 41, pp. 14242-14253. DOI: 10.1523/JNEUROSCI.1321-12.2012. 1748.

35. Morgan I.G., Ohno-Matsui K., Saw S.M. Myopia. Lancet, 2012, vol.379, no. 9827, pp. 1739-

36. Pan C.W., Cheng C.Y., Saw S.M., Wang J.J., Wong T.Y. Myopia and age-related cataract: a systematic review and meta-analysis. Am. J. Ophthalmol, 2013, vol. 156, no.5, pp. 1021-1033.

37. Navarro R., Santamaría J., Bescós J. Accommodation-dependent model of the human eye with aspherics. Journal of the Optical Society of America A, 1985, vol. 2, no. 8, pp. 1273-1280. DOI: 10.1364/JOSAA.2.001273.

38. Nissen C., Sander B., Lund-Andersen H. The Effect of Pupil Size on Stimulation of the Melanopsin Containing Retinal Ganglion Cells, as Evaluated by Monochromatic Pupillometry. Frontiers in Neurology, 2011, vol. 2, pp. 92. DOI: 10.3389/fneur.2011.00092 
39. Plainis S. Accommodative response: Physiology and Behaviour. 10th Aegean Summer School in Visnal Optics Hevsnisos Crete 02.10-04.10, 2011. Available at: http://publicana.ru/files/mehanizmakkommodacii-glaza.pdf (24.10.2016).

40. Plainis S., Ginis H.S., Pallikaris A. The effect of ocular aberrations on steady-state errors of accommodative response. J.Vis., 2005, vol.5, no. 7, pp.466-477.

41. Jung S.K., Lee J.H., Kakizaki H., Jee D. Prevalence of Myopia and its Association with Body Stature and Educational Level in 19-Year-Old Male Conscripts in Seoul, South Korea. Invest Ophthalmol. Vis. Sci., 2012, vol. 53, no. 9, pp. 5579-5583. DOI: 10.1167/iovs.12-10106.

42. Brainard G.C., Hanifin J.P., Warfield B., Stone M., James M., Ayers M., Kubey A., Byrne B., Rollag M. Short wavelength enrichment of polychromatic light enhances human melatonin suppression potency. J. Pineal. Res., 2015, vol. 58, pp. 352-361.

43. Sliney D.H. Health and safety implications of new lighting technologies. Light and Engineering, 2010, vol. 18, no. 4, pp.20-22

44. Tarrant J., Roorda A., Wildsoet C.F. Determining the accommodative response from wavefront aberrations. Journal of Vision, 2010, vol. 10, no. 5, pp. 4.

45. Feigl B.L., Zele A.J., Fader S.M., Howes A.N., Hughes C.E., Jones K.A., Jones R. The postillumination pupil response of melanopsin-expressing intrinsically photosensitive retinal ganglion cells in diabetes. Acta Ophthalmol, 2012, vol. 90, no. 3, pp. 230-234. DOI: 10.1111/j.1755-3768.2011.02226.x.

46. Watson A.B., Yellott J.I. A unified formula for light-adapted pupil size. Journal of Vision, 2012, vol. 12, no. 12, pp. 1-16. DOI:10.1167/12.10.12.

Kaptsov V.A., Dainego V.N. Disorders in melanopsin effect of pupil constriction as a risk factor causing eye diseases. Health Risk Analysis, 2017, no. 1, pp. 124-137. DOI: 10.21668/health.risk/2017.1.15.eng

Received: 24.11.2016

Accepted: 02.03.2017

Published: 30.03.2017 